\title{
Beata Glinkowska*
}

\section{Potrzeba przynależności - elementarna czy rzędu wyższego?}

\section{Wstęp}

Hierarcha potrzeb A. Maslowa jest najbardziej znaną koncepcją, należącą do grupy teorii treści motywacji. Nie wgłębiając się w istotę poszczególnych kategorii potrzeb tam występujących, w artykule skupiono się na idei potrzeby przynależności. Z uwagi na zauważalną w literaturze niespójność związaną z jej rangą, także istnienie luk badawczych w tym względzie, podjęto próbę odpowiedzi na pytanie, czy jest ona dla każdego pracownika jednakowo ważna dla zaangażowania się w pracę, czy jej zaspokojenie jest powodem zwiększenia lojalności, kreatywności, czego konsekwencją może być lepsza skuteczność w osiąganiu celów własnych i organizacyjnych. Ponadto, przedmiotem zainteresowań autorki artykułu stało się dociekanie, czy potrzeba ta jest jednakowo ważna w grupie pracowników i w grupie osób, które są dorosłe, ale jeszcze pracy nie podjęły. $\mathrm{Z}$ tego względu próbę badawczą stanowią pracownicy i studenci studiów dziennych, jako, że studenci studiów zaocznych zwykle już są zatrudnieni. Badania ankietowe wykonane zostały dwuetapowo:

- w grudniu 2013 roku próbę badawczą stanowili pracownicy trzech firm z województwa łódzkiego (magazyn logistyczny, przedsiębiorstwo produkujące odzież damską, przedsiębiorstwo produkcyjne $\mathrm{z}$ technologią CNC). Łącznie była to zbiorowość o liczbie 47 pracowników, reprezentujących różne działy i poziomy: od kierowników po pracowników wykonawczych i od księgowych po technologów oraz pracowników produkcji. Był to dobór celowy z uwagi na dostępność próby;

- w lutym 2015 roku poszerzono badania o grupę ludzi młodych, którzy - w większości przypadków - jeszcze zawodowo nie pracowali. Ideą tej części badań było sprawdzenie w jaki sposób młodzi ludzie postrzegają tę potrzebę. Czy dla nich jest to potrzeba elementarna, czy wyższego rzędu?

\footnotetext{
* Dr, adiunkt, Katedra Zarządzania, Wydział Zarządzania, Uniwersytet Łódzki.
} 
Próbę badawczą stanowili studenci Politechniki Łódzkiej, studiów dziennych uzupełniających magisterskich z kierunku Budownictwo. Łącznie było to 127 osób. Był to także dobór celowy.

Skonfrontowanie tych dwóch środowisk: pracujących i studentów (potencjalnych przyszłych pracowników), było przez autorkę zamierzone, bowiem dokonała próby porównania oczekiwań aktualnych pracujących z przyszłymi pracującymi.

Ważnym wkładem w badania są też wyniki obserwacji uczestniczącej, jako uczestniczki organizacji, których konsekwencją są wnioski własne.

\section{Hierarchia potrzeb ze szczególnym uwzględnieniem potrzeby przynależności}

W literaturze związanej z tematem pracy można doszukać się wielu koncepcji i metod motywacji pracowników do pracy w celu zwiększenia skuteczności ich działań, przekładających się finalnie na efektywność organizacyjną, mierzoną stosunkiem sumy efektów do sumy nakładów (Sierpińska, Jachna 2007). Jeżeli z okresu na okres wyniki związane z efektywnością zwiększają się, to przedsiębiorcy i menedżerowie zwykle uważają stosowane przez siebie metody za skuteczne. Każde nauczanie, każda praca, wychowanie itp., powinny być celowe i skuteczne. T. Kotarbiński skutecznym nazywał „takie działanie, które prowadzi do skutku zamierzonego jako cel” (Kotarbiński 1975: 104).

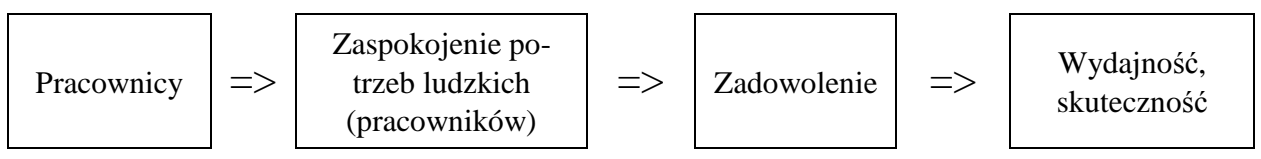

Rysunek 1. Proces motywacji według podejścia od strony potrzeb

Źródło: opracowanie własne na podstawie Kozłowski (2010: 36).

Wśród mnogości koncepcji związanych z potrzebami człowieka, na pierwszy plan wyłania się piramida potrzeb A. Maslowa. Wydaje się ona ponadczasową i uniwersalną koncepcją związaną z motywowaniem ludzi do pracy ${ }^{1}$. Należy

${ }^{1}$ Autorka niniejszego opracowania jest przekonana o praktycznej słuszności tej koncepcji. Wynika to z jej kilkunastoletniego doświadczenia zawodowego nabytego przy pełnieniu roli menedżera. 
do teorii treści, odpowiadających na pytanie: jakie czynniki motywują ludzi do pracy? Według niej siła motywacyjna jest we wnętrzu jednostki. Skoro potrzeby ukryte wewnątrz człowieka domagają się zaspokojenia, to po ich zaspokojeniu następuje zadowolenie, które przekłada się na wzrost wydajności pracy, co efektywnie wpływa na funkcjonowanie całej organizacji (Forsyth 2004: 21). Zależność tę przedstawiono na rysunku 1.

Zgodnie z założeniami piramidy A. Maslowa, potrzeby ludzkie zaspokajane są zwykle stopniowo i w określonej kolejności. Najpierw zaspokajane są potrzeby elementarne (fizjologiczne i bezpieczeństwa), a następnie potrzeby tzw. rzędu wyższego (uznania i samorealizacji). Potrzeby przynależności leżą pośrodku piramidy i jedni uznają je za elementarne, a inni za rzędu wyższego. Według A. Maslowa potrzeby przynależności to: kontakty z ludźmi, spotkania, zarówno z kolegami z pracy, jak i ze znajomymi, przyjaciółmi, rodziną, relacje z nimi, towarzysząca temu więź i akceptacja. Psychologowie są zdania, że człowiek musi przynależeć do jakiejś grupy społecznej, jednakże potrzeba ta jest w pełni zaspokojona tylko wówczas, gdy w danej organizacji (lub w jakiejś grupie) będzie w akceptowany i zaspokojony poziom wyższy w zakresie potrzeb człowieka, do którego należą potrzeby uznania organizacji (Forsyth 2004: 22). Teoria piramidy potrzeb nie objaśnia całego procesu, lecz kluczowe jego elementy organizacji (Forsyth 2004: 22). R. Karaś jest zdania, że hierarchia potrzeb opracowana jest wyłącznie na podstawach teoretycznych, bowiem badania empiryczne nie wykazały jej uniwersalnej i praktycznej postaci. Nie uwzględniono też w niej kluczowych czynników, np.:

- zjawiska frustracji, czyli braku możliwości zaspokojenia potrzeby wyższej, mimo że potrzeba niższa została zaspokojona;

- zjawiska regresji, czyli poczucia braku określonej potrzeby, pomimo, że wcześniej była zaspokojona;

- problemu, czyli odpowiedzi na pytanie, czy człowiek może odczuwać potrzeby wyższe, jeżeli niższe nie zostały zaspokojone (Karaś 2003: 18).

Sam A. Maslow doszedł do wniosku, że stworzona przez niego koncepcja może ulegać zmianie i, że nie posiada charakteru uniwersalnego (Karaś 2003: 18-19). Autorka artykułu jest zdania, że pomimo niedoskonałości tego narzędzia, jest ono na tyle uniwersalne, że można $\mathrm{w}$ wielu przypadkach $\mathrm{z}$ powodzeniem stosować je dla prawidłowego motywowania ludzi do pracy. Opinia taka wynika z kilkunastoletniej praktyki o charakterze menedżera.

Charakterystykę potrzeb według koncepcji A. Maslowa zawarto w tabeli 1.

Człowiek ma rozmaite potrzeby. Ich siła różni się między poszczególnymi jednostkami ze względu na indywidualne uwarunkowania. $\mathrm{W}$ tabeli przedstawiona jest podstawowa i ogólna charakterystyka potrzeb, zgodnie z chronologią zaproponowaną w piramidzie przez A. Maslowa. Istotą teorii potrzeb jest to, 
że zachowania człowieka w dążeniu do równowagi są określone przez dwie grupy potrzeb - tych związanych $\mathrm{z}$ niedoborem, niedostatkiem i tych związanych z rozwojem, wzrostem.

Tabela 1. Charakterystyka grup potrzeb według A. Maslowa

\begin{tabular}{|c|c|c|c|}
\hline \multirow{2}{*}{$\begin{array}{l}\text { POTRZEBY } \\
\text { (Grupa } \\
\text { potrzeb) }\end{array}$} & \multirow{2}{*}{$\begin{array}{c}\text { CHARAKTERY } \\
\text { STYKA }\end{array}$} & \multicolumn{2}{|c|}{$\begin{array}{l}\text { PRZYKŁADY POTRZEB } \\
\end{array}$} \\
\hline & & $\begin{array}{c}\text { W ŻYCIU } \\
\text { CODZIENNYM }\end{array}$ & W ORGANIZACJI \\
\hline fizjologiczne & $\begin{array}{l}\text { Podstawowe } \\
\text { sprawy } \\
\text { przetrwania } \\
\text { i biologicznego } \\
\text { funkcjonowania. }\end{array}$ & $\begin{array}{l}\text { - powietrze } \\
\text { - żywność } \\
\text { - seks } \\
\text { - pragnienie }\end{array}$ & $\begin{array}{l}\text { - płace } \\
\text { - oświetlenie } \\
\text { - sanitariaty } \\
\text { - temperatura powietrza }\end{array}$ \\
\hline bezpieczeństwa & $\begin{array}{c}\text { Potrzeba } \\
\text { stabilnego } \\
\text { środowiska } \\
\text { psychicznego oraz } \\
\text { emocjonalnego }\end{array}$ & $\begin{array}{l}\text { - mieszkanie } \\
\text { - branie } \\
\text { - życie wolne od } \\
\text { - trosk materialnych }\end{array}$ & $\begin{array}{l}\text { - ciągłość zatrudnienia } \\
\text { - } \text { system zabezpieczenia } \\
\text { - emerytalnego } \\
\text { i rentowego } \\
\text { - zasiłek dla } \\
\text { bezrobotnego } \\
\text { - mieszkanie służbowe }\end{array}$ \\
\hline przynależności & $\begin{array}{l}\text { Potrzeba miłości } \\
\text { i akceptacji przez } \\
\text { otoczenie }\end{array}$ & $\begin{array}{l}\text { - rodzina } \\
\text { - stosunki } \\
\text { towarzyskie } \\
\text { - przyjaźń } \\
\end{array}$ & $\begin{array}{l}\text { - zespołowe formy } \\
\text { - pracy, np. grupy } \\
\text { robocze } \\
\text { - } \text { społeczne interakcje }\end{array}$ \\
\hline szacunku & $\begin{array}{c}\text { Zewnętrzne } \\
\text { (potrzeba uznania } \\
\text { i szacunku } \\
\text { w oczach innych); } \\
\text { Wewnętrzne } \\
\text { (potrzeba } \\
\text { pozytywnego } \\
\text { obrazu we } \\
\text { własnych oczach) }\end{array}$ & $\begin{array}{l}\text { - status społeczny } \\
\text { - uznanie }\end{array}$ & $\begin{array}{l}\text { - stanowisko } \\
\text { - tytuł służbowy } \\
\text { - pomieszczenie służbowe } \\
\text { - samochód służbowy }\end{array}$ \\
\hline samorealizacji & $\begin{array}{c}\text { Osiąganie przez } \\
\text { jednostki ciągłego } \\
\text { rozwoju oraz } \\
\text { indywidualnego } \\
\text { wzrostu }\end{array}$ & $\begin{array}{l}\text { - osiągnięcia } \\
\text { - odpowiedzialność } \\
\text { - autonomia }\end{array}$ & $\begin{array}{l}\text { - samorealizacja } \\
\text { - szkolenia } \\
\text { - autonomia w pracy } \\
\text { - partycypacja } \\
\text { - w zarzadzaniu }\end{array}$ \\
\hline
\end{tabular}

Źródło: Karaś (2003: 17). 
Potrzeby przynależności są przykładem potrzeb społecznych i chyba najbardziej sprzecznie charakteryzowane są w literaturze przedmiotu. Ich interpretacją zajmują się psychologowie, ekonomiści, socjolodzy, praktycy. Rozpatrywane są z perspektywy osób sprawnych i niepełnosprawnych. Zauważono bowiem, że człowiek poszukuje w drugiej osobie przede wszystkim miłości, ciepła, czułości czy więzi. Uczestniczenie $\mathrm{w}$ organizacji daje przeświadczenie, że poczucie więzi i przynależności jest ważne. Niezaspokojenie tych potrzeb może rzutować na całe życie człowieka. Niektórzy uważają, że potrzeba przynależności bierze swoje źródło w potrzebie bezpieczeństwa, bowiem jego brak wygasza świadomość pozostałych potrzeb. Przynależność zmniejsza poczucie niepewności, zagrożenia i pomaga w zaspokojeniu potrzeby akceptacji i uznania. Akceptowanie, to prawo do bycia sobą, posiadanie własnego zdania, ale też zdolność słuchania (Olechnowicz 1979: 6). J. Vanier jest zdania, że aby człowiek mógł czuć się bezpiecznie i odnaleźć swoje miejsce w świecie, musi przede wszystkim poczuć swoją przynależność do jakiejś grupy (Vanier 1984: 108; Vanier 1991: 19-20).

Każdy człowiek potrzebuje relacji z innymi, budowania z nimi więzi. Poza codziennymi, towarzyskimi kontaktami, potrzebuje szczerej rozmowy, aby słuchać i być wysłuchanym. Kontakt umysłowy, emocjonalny i fizyczna obecność często pobudzają wyobraźnię, powodują dzielenie się doświadczeniami, dają poczucie rozumienia i zrozumienia. Są powodem odnalezienia własnej tożsamości (Garczyński 1972: 90).

Analizy licznych badań naukowych potwierdzają, że wszyscy ludzie odczuwają potrzebę przynależności i utrzymywania pozytywnych relacji (Kenrick, Neuberg, Cialdini 2006: 41-47). Geneza tych potrzeb wywodzi się z wczesnych doświadczeń emocjonalnych już w życiu rodzinnym dziecka i według A. Maslowa jest to najczęściej sfrustrowana grupa, stąd pojawiają się często zachowania patologiczne lub nieprzystosowawcze.

Istotny wpływ na postrzeganie potrzeb przynależności i ich rolę $\mathrm{w}$ życiu człowieka wywarł eksperyment S. Schachtera, dający dowód, że osoby spodziewające się przykrości, wolą w tym czasie przebywać w grupie, bowiem obecność innych osób wpływa na nie kojąco. Tak silnej potrzeby afiliacji nie mają osoby, które nie spodziewają się niczego przykrego (Schachter 1963: 757-768). Ponadto, przebywanie z innymi daje szansę na dzielenie się wiedzą, czy wymianę informacji.

Poziom odczuwania potrzeb u każdego człowieka może być inny. Wynika to $\mathrm{z}$ wielu przesłanek, np. wychowanie, sposób życia, osobiste doświadczenia, stan ducha, stanowisko, rodzaj pracy, wiek, styl kierowania, osobiste zainteresowania. Wiele ze społecznych zachowań skierowanych jest na wytworzenie silnych związków przynależności, połączonych z pragnieniem afiliacji. Ludzie boją się odrzucenia, pragną przyjaźni, szacunku. 


\section{Kształtowanie atmosfery przynależności w pracy}

J. Penc jest zdania, że organizacja może funkcjonować sprawnie, jeżeli stosunki między ludźmi są harmonijne, jeśli jest zgoda, dążenie do wspólnie uznanego celu, jakim jest dobro organizacji. Dobre stosunki między uczestnikami organizacji, życzliwość i chęć współpracy, „tworzą określony ład psychospołeczny, który sprzyja dobrej współpracy i umacnia więzi rzeczowe, tj. koncentrowanie się ludzi na sprawach pracy" (Penc 2001: 86). Autor ten zauważa także, że tworzenie odpowiedniego klimatu organizacyjnego jest zadaniem dla menedżerów. Podobnego zdania jest B. Kaczmarek, który podkreśla rolę kierownictwa w tworzeniu kultury organizacyjnej opartej na atmosferze przynależności (Kaczmarek 2013: 90-95). Klimat organizacyjny może potocznie być uznany za kulturę organizacyjną danej firmy, w której skład wchodzą zależności formalne i nieformalne ${ }^{2}$. Podobnie jak kultura organizacyjna, składają się na niego także: zespół norm i zasad postępowania, wzajemne stosunki i różnorodne więzi. „Klimat organizacyjny poprzez modelowanie nastawienia i sposobów odnajdywania miejsca w organizacji przez jej uczestników, precyzuje kierunek określający tym samym skalę ich aktywności" (Bratnicki 1980: 86). Kształtuje on wiele czynników o charakterze wewnętrznym i zewnętrznym, które łącznie wpływają na postawy pracowników, ich samopoczucie, odczucia, stopień zadowolenia i identyfikacji z firmą. Zapewnienie porządku, ładu, spokoju i harmonii między ludźmi, dobre relacje z szefem są podstawą zaspokojenia potrzeby przynależności. Często jest to warunkiem koniecznym współpracy i współdziałania pracowników w danej organizacji. Ludzie chętniej dzielą się informacjami, wiedzą i doświadczeniem, jeżeli klimat organizacyjny w pracy jest przyjazny. Pomagają też sobie często w sytuacjach, gdy ich umiejętności różnią się, są niejednakowe, uzupełniając się w wykonywaniu konkretnych czynności. Mając zaufanie do siebie, mogą o wiele częściej liczyć na wzajemną pomoc, niż Ci, którzy znajdują się w atmosferze nieufności.

W każdej organizacji można wyróżnić wiele więzi, przy czym rodzaj więzi jest warunkiem wydzielenia się dwóch grup: formalnych i nieformalnych (Haber 1998: 207-209; Griffin 2010: 527-529). Już dość dawno M. Armstrong zauważył, że członkowie zespołu łatwiej się identyfikują, jeśli lubią innych ludzi pracujących w danych grupach, zespołach, organizacji, także jeżeli pragną być kojarzeni przez innych pracowników z danym zespołem (Armstrong 1997: 142). Grupy formalne powstają z mocy prawa i funkcjonują w danej strukturze organizacyjnej. Ich istotą są oficjalne (rzeczowe) więzi o charakterze regulowanym

${ }^{2}$ Autorka podkreśla, że te dwa pojęcia utożsamia jedynie potocznie. W literaturze istnieje niespójność podejść, jednakże B. Mikuła dostrzega wiele różnic w pojęciach: kultura organizacyjna a klimat organizacyjny (zob.: Mikuła 2000). 
zasadami i statutami. Grupy nieformalne, to grupy o więziach spontanicznych i nieoficjalnych, tworzące się samoistnie, bez regulaminów i przepisów prawa. W ich tworzeniu pomagają wspólne zainteresowania, hobby, podobne oczekiwania i doświadczenia. Menedżerowie powinni zwrócić szczególną uwagę na grupy nieformalne, bowiem stanowią one wielką siłę:

- utrwalają wartości społeczne i kulturowe;

- zapewniają zadowolenie i bezpieczeństwo;

- ułatwiają porozumiewanie;

- pomagają w rozwiązywaniu problemów (Stoner, Wankel 1997: 410).

Kształtowanie potrzeb przynależności i ich zaspokajanie jest istotną sprawą dla skuteczności działań w organizacji, co może przełożyć się na lepszą efektywność, czy skuteczność działań. Przekonanie takie można odnaleźć w poglądach R. W. Griffina, J. Penca czy M. Warda. Przekonana jest też o tym autorka niniejszego artykułu, która przeprowadzała w tej kwestii badania własne. Poczucie wspólnych celów i wartości umacnia współdziałanie i współpracę. Zaspokojone potrzeby przynależności powinny wpłynąć na lepszą efektywność każdej grupy (zespołu) w organizacji. W atmosferze przynależności członkowie zespołu łatwiej znajdują sposoby rozwiązania problemów. Efektywność grupy można rozpatrywać jako funkcję trzech zmiennych: współzależności zadań, poczucia siły i współzależności wyników (Stoner, Freeman, Gilbert 1997: 492-493). Wymienione tu zmienne ściśle z sobą współdziałają. Współzależność zadań jest stopniem współdziałania członków zespołu, natomiast współzależność wyników jest stopniem ich skuteczności, osiągania przez nich celów. Grupa jest skuteczna wówczas, gdy ma wspólny cel. Najlepiej, aby uczestniczyła w jego formułowaniu. Wyzwala się wtedy poczucie uczestnictwa, zwiększa się przekonanie o przynależności i lojalności, pojawia się kreatywność. Kierownictwo firmy powinno więc zapewnić taką atmosferę przynależności i organizację grup, aby mogły być one entuzjastyczne i efektywne. To szczególne zadanie dla menedżerów współczesnej firmy, w której kierownik (menedżer) powinien być inspiratorem i coachem, jednoczącym ludzi wokół wspólnych celów, wspierającym ich działania. Wielu pracowników nie potrafi ani pracować, ani odnaleźć się w grupach, które nie są zintegrowane, w których nie ma więzi społecznych. Następuje alienacja, niechęć przychodzenia do pracy, czy jej wykonywania. Zdarza się też, że osoby, które czują wyobcowanie, szukają możliwości odcięcia się od konieczności przebywania w grupie osób, która ich nie akceptuje. Korzystają wówczas zwykle ze zwolnień lekarskich z rozmaitych powodów (rzeczywistych i nierzeczywistych). 


\section{Potrzeba przynależności w świetle badań}

Badanie zostało przeprowadzone dwuetapowo. W etapie pierwszym respondenci (pracownicy i studenci) rozwiązywali test dotyczący zidentyfikowania wartości, które są dla nich ważne. Narzędziem badawczym był test „Twojego systemu wartości i przekonań” opracowany przez E. Strzelecką, speca od zarządzania (Strzelecka 2000: 15-16). Respondentami były dwie grupy: pracownicy zajmujący bardzo zróżnicowane stanowiska i szczeble oraz studenci studiów dziennych uzupełniających magisterskich z kierunku Budownictwo na Politechnice Łódzkiej. Badania odbyły się w różnych terminach i w innych miejscach. Wykonywane były osobiście podczas dwu adekwatnych spotkań, zatem zwrot odpowiedzi był stuprocentowy: 47 pracowników i 127 studentów. Dobór próby w obu przypadkach był celowy i wynikał z dostępności próby i indywidualnych kontaktów, jednakże był też zamierzony, bowiem jego celem było skonfrontowanie dwóch prób: pracowników i przyszłych pracowników. W wyniku badań dokonano próby odpowiedzi na pierwsze pytanie problemowe, czy potrzeba przynależności jest jednakowo ważna dla obu grup i jak wypada na tle innych potrzeb. Wyniki badań przedstawiono w tabeli 2 .

Tabela 2. Wyniki badań dotyczące identyfikacji potrzeb

\begin{tabular}{|l|c|c|}
\hline \multicolumn{1}{|c|}{ Grupa potrzeb } & Pracownicy & Studenci \\
\hline Fizjologiczne & $4(8,5 \%)$ & $17(13,38 \%)$ \\
\hline Bezpieczeństwa & $32(68,10 \%)$ & $51(40,15 \%)$ \\
\hline Przynależności & $6(12,77 \%)$ & $29(22,83 \%)$ \\
\hline Uznania & $4(8,5 \%)$ & $11(8,6 \%)$ \\
\hline Samorealizacji & $1(2,13 \%)$ & $19(14,95 \%)$ \\
\hline Razem & $47(100 \%)$ & $127(100 \%)$ \\
\hline
\end{tabular}

Źródło: opracowanie własne.

$\mathrm{Z}$ analizy danych zawartych w tabeli wynika, że w obu grupach przeważa chęć zaspokojenia potrzeb bezpieczeństwa $(68,1 \%$ - pracownicy i $40,15 \%$ - studenci), przy czym w grupie studentów siła świadomości tych potrzeb słabnie na korzyść potrzeb przynależności, których świadomość w tej grupie jest z kolei wyższa niż w grupie pracowników (12,77\% - pracownicy i 22,83\% - studenci). $\mathrm{Z}$ uwagi na możliwość przeprowadzenia swobodnego wywiadu, dodatkowo uzyskano informację, że większość pracowników nie była zadowolona z wysokości wynagrodzeń na swoich stanowiskach. Studenci zaś wierzyli w to, że potrzeby bezpieczeństwa są ważne, ale że będą w stanie bezwarunkowo je w przyszłych pracach zaspokoić. W grupie studentów też, częściej niż w grupie pracowników, 
potrzeby bezpieczeństwa zbliżały się (według wykonanych przez nich wykresów) do potrzeb przynależności. W obu grupach porównywalne wartości uzyskano co do świadomości zaspokajania potrzeb uznania, jednakże są one na stosunkowo niskim poziomie (ok. 8,5\% w każdej grupie).

Kolejna część badań dotyczyła odpowiedzi na pytanie, czy potrzeba przynależności jest ważna dla zaangażowania się pracowników w pracę, czy świadomość przynależności ma wpływ na zwiększenie ich lojalności i kreatywności, czego konsekwencją może być lepsza skuteczność w osiąganiu celów własnych i organizacyjnych, czy polepszenie efektywności. W tym celu respondenci mieli za zadanie odpowiedzieć na siedem pytań zawartych w specjalnie opracowanym kwestionariuszu ankiety.

Respondenci zgodnie stwierdzili, że klimat organizacyjny jest ważny dla poczucia przynależności do grupy. Uznali realizację potrzeb przynależności za istotną dla zaangażowania się w pracę i dla zwiększenia ich lojalności. Zdecydowana większość (średnio 84\%; obie grupy były tu zgodne) uznało, że akceptacja przez członków grupy wpływa pozytywnie na realizację celów organizacyjnych. Wszyscy respondenci wyrazili przekonanie, że skuteczność realizowanych zadań i celów zwiększa się przy pozytywnej atmosferze (dobry klimat organizacyjny). Mniejszość (16\%) respondentów (studenci) nie wyraziła opinii co do rangi potrzeb przynależności w ich życiu. Na pytanie o sklasyfikowanie tej grupy potrzeb do kategorii: elementarne, rzędu wyższego, zakreślili odpowiedź: nie wiem. Nie było jednakże odpowiedzi potwierdzającej, że potrzeby przynależności należą do rzędu wyższego (wg piramidy A. Maslowa). W wywiadzie swobodnym okazało się, że badani studenci wolą realizować indywidualne projekty i nie lubią pracy zespołowej. Wolą opracowywać sami powierzane im zadania, a jeśli praca wymaga pracy zespołowej, to rzadko się afiliują. Jednak należy też zauważyć, że dotąd nie byli oni pracownikami żadnej organizacji, przynależą jednak do społeczności akademickiej. To może świadczyć o specyficznych cechach charakteru, albo o braku doświadczenia w sytuacji bycia pracownikiem, uczelnia bowiem daje dość dużą swobodę działania i zachowania przy realizacji toku studiów. Reasumując, można zatem uznać, że zaspokojenie potrzeb przynależności jest dla większości pracowników potrzebą elementarną. Ku potwierdzeniu takiego wyniku skłania się też autorka niniejszego artykułu. Wyniki badań potwierdziły też postawioną hipotezę o pozytywnym związku dobrego klimatu organizacyjnego i poczucia przynależności do organizacji.

\section{Podsumowanie}

Zgoda, harmonia, przyjazna atmosfera, odpowiedni klimat organizacyjny są czynnikami, które w pozytywny sposób wpływają na wykonywanie każdej pracy. Należą też do determinant kształtowania specyfiki organizacji i tworzenia 
takich warunków, w których pracownicy chętniej dzielą się wiedzą. Człowiek pragnie przynależeć do jakiejś społeczności. Lepiej się czuje, gdy jest akceptowany w pracy, lepiej także wykonuje swoją pracę, co wpływa pozytywnie na osiąganie celów organizacyjnych i poprawienie efektywności pracy. Badania wykonane $\mathrm{w}$ dwóch różnych grupach pokazały, że potrzebę przynależności można uznać za elementarną. Respondenci wyraźnie podkreślali też, że jeżeli czują się częścią społeczności, to w większym stopniu angażują się w powierzone im obowiązki, czy zadania. Wykonane badania nie uogólniają wyników, ale są potwierdzeniem posiadanych przez autorkę przypuszczeń.

\section{BIBLIOGRAFIA}

Armstrong M. (1996), Zarządzanie zasobami ludzkimi, Kraków.

Bratnicki M. (1980), Diagnoza klimatu organizacyjnego $w$ procesie doskonalenia organizacji, „Ekonomika i Organizacja Pracy”, nr 8-9.

Forsyth P. (2004), Jak motywować ludzi, HELION, Gliwice.

Garczyński S. (1972), Potrzeby psychiczne. Niedosyt. Zaspokojenie, Warszawa.

Griffin R. W. (2010), Podstawy zarządzania organizacjami, Warszawa.

Haber L. H. (1998), Management. Zarys zarzadzania mała firma, Kraków.

Kaczmarek B. (2013), Wspótczesne wyzwania dla zarządzania przedsiębiorstwami, Toruń.

Karaś R. (2003), Teorie motywacji w zarzadzaniu, Wydawnictwo Akademii Ekonomicznej w Poznaniu, Poznań.

Kenrick D. T., Neuberg S. L., Cialdini R. B. (2006), Psychologia społeczna. Rozwiąane tajemnice, Gdańsk.

Kotarbiński T. (1975), Traktat o dobrej robocie, Ossolineum, Wrocław.

Mikuła B. (2000), Człowiek a organizacja. Humanizm w koncepcjach $i$ metodach organizacji i zarządzania $X X$ wieku, Kraków.

Olechnowicz H. (1979), Potrzeby psychiczne dzieci głębiej upośledzonych umystowo, [w:] Olechnowicz H. (red.), Wychowanie i nauczanie głębiej upośledzonych, Warszawa.

Penc J. (2001), Kreowanie zachowań w organizacji, Warszawa.

Schachter S. (1963), Birth order, eminence, and higher education, „American Sociological Review", vol. 28.

Sierpińska M., Jachna T. (2007), Ocena przedsiębiorstwa wedtug standardów światowych, Warszawa.

Stoner J. A. F., Wankel Ch. (1997), Kierowanie, Warszawa.

Stoner J. A. F., Freeman E. E., Gilbert D. E. (1997), Kierowanie, Warszawa.

Strzelecka E. (2004), Kompetencje społeczne w podejmowaniu własnej działalności gospodarczej, [w:] Samozatrudnienie. Poradnik dla kreatywnych, Akademickie Biuro Karier, Uniwersytet Medyczny w Łodzi, Łódź.

Vanier J. (1984), Mężczyzna i niewiasta stworzyt ich do życia w prawdziwej mitości, Kraków.

Vanier J. (1991), Wspólnota miejscem radości i przebaczenia, Warszawa. 


\title{
The need to belong - an elementary or higher - order need?
}

\begin{abstract}
SUMMARY
The essence of the article is to present the results of studies that have been conducted on a sample of 47 employees and 127 students. The purpose was to investigate whether the need to belong is an important factor for the employees to fully engage in their work, if the consciousness of belonging increases employees' loyalty, their creativity, and arises with an improvement of the effectiveness in achieving organizational and their own goals. Theoretical analysis was intentionally based on the "iconic" literature (Stoner, Wankel, Freeman, Gilbert, Griffin, Penc, Kotarbinski). In the first part of the article analyzed was the theory of hierarchy of needs with particular emphasis of the need for belonging, then it was referred to the creation of the atmosphere of belonging to the organization. The third section presents the results obtained in the research. The assumptions presented in the introduction were confirmed.
\end{abstract}

